\title{
O que você esconde? Caminhos para uma decolonização do "universalismo sem corpo"
}

\author{
What do you hide? Paths to a decolonization of the \\ "Universalism without a body".
}

Thiago de Abreu e Lima Florencio

Doutor em Literatura, Cultura e Contemporaneidade - PUC-RIO

Universidade Regional do Cariri

thiagoabreuflorencio@gmail.com

\begin{abstract}
Resumo: Este artigo discute criticamente, em diálogo com Aimé Césaire, Frantz Fanon e alguns autores decoloniais, a ideia do "universalismo sem corpo". Trata-se de um princípio epistemológico fundamentado na lógica disjuntiva entre sujeito e objeto, mente e corpo, que acompanha a constituição do capitalismo colonial. Nesse princípio, o colonizador se inscreve enquanto sujeito universal incorpóreo ao tempo que o "outro" é objetificado, reduzido à sua existência particular e corporal. Tendo em vista esse paradigma ocidental que afasta o corpo dos processos de subjetivação e construção de saberes, proponho um caminho experimental de "escrita despacho", cujo princípio é acionar um pensamento atravessado pelas forças vitais do corpo, de modo que rompa com as amarras de uma pedagogia incorpórea que atravessa a cidade e seus monumentos, as escolas e seus métodos escriptocêntricos.
\end{abstract}

Palavras-chave: Colonialidade, Corpo, Epistemologias decoloniais.

\begin{abstract}
This article discusses critically, in dialogue with Aimé Césaire, Frantz Fanon and some decolonial authors, the ideia of "fleshless universalism". It is an epistemological principle based on the disjunctive logic between subject and object, mind and body, which accompanies the constitution of colonial capitalism. In this principle, the colonizer inscribes himself as an incorporeal universal subject while the other is objectified, reduced to his particular and corporal existence. In view of this Western paradigm that takes the body away from the processes of subjectivation and construction of knowledge, I propose an experimental way of dispatch writing, whose principle is to trigger a thought crossed by the vital forces of the body, so that it breaks with the bonds of incorporeal pedagogy that runs through the city and its monuments, schools and its scripocentric methods.
\end{abstract}

Keywords: Coloniality, Body, Decolonial epistemologies. 


\section{A pedagogia do "universalismo sem corpo"}

Este artigo ensaia uma experiência de combate à pedagogia do universalismo sem corpo ou, pensando a partir de Aimé Césaire, de combate à pedagogia do "universalismo descarnado". Trago esse conceito de Césaire para invocar meu corpo em seus deslocamentos pela cidade e seus monumentos coloniais, pela escola e suas pedagogias de anulação do corpo, pelos cadernos e seus sistemas escriptocêntricos e, a partir daí, propor uma escrita decolonizadora. Decolonizadora no sentido de que busca romper com as amarras desta pedagogia que não só anula o corpo dos processos de ensino-aprendizagem, como também anula o corpo de sua própria presença, ou seja, de seu direito de existir em sua singularidade e de ocupar um lugar próprio. A experiência do desterro existencial e epistemológico referente aos corpos colonizados está na raiz da formulação de nossos currículos eurocentrados e de suas políticas de sistemática reiteração da impossibilidade de existirmos a partir de nossos próprios corpos, histórias, memórias e produções de subjetividade.

Foi numa carta de rompimento com o Partido Comunista francês, do qual era até então filiado, que Aimé Césaire trouxe pela primeira vez o termo "universalismo descarnado". Acusado pelos membros do partido de ser "provincianista" em razão de sua compreensão da necessidade de considerar as singularidades dos processos históricos de exploração dos povos negros, Césaire responde atacando o "universalismo abstrato do pensamento marxista eurocêntrico.".

Provincianismo? De jeito nenhum. Não me fecho em particularismos estreitos. Mas tampouco quero perder-me num universalismo descarnado. Há duas maneiras de se perder: por segregação amuralhada no particular, ou por dissolução no universal. Minha concepção do universal é o de um universal depositário de todo o particular, depositário de todos os particulares, aprofundamento e coexistência de todos os particulares. (CÉSAIRE, Carta a Maurice Thorez, 1956 - grifo meu)

O termo "descarnado" seria, segundo Césaire, a manifestação dessa "dissolução no universal", ou seja, um movimento epistêmico que esconde seu lugar de enunciação, seu particularismo hegemônico (GROSFOGUEL, 2007: 71). Tal movimento ganhou impulso a partir do avanço colonial seiscentista, mas se solidificou com o advento da 
filosofia cartesiana. O princípio do ego cogito, em seu dualismo ontológico entre mente e corpo, constitui uma "nova id-entidade, a "razão/sujeito", a única entidade capaz de conhecimento "racional", em relação à qual o "corpo" é e não pode ser outra coisa além de "objeto" de conhecimento" (QUIJANO, 2005: 129). Essa operação epistemológica cartesiana de separação radical entre sujeito e objeto marcaria, segundo Gumbrecht, a constituição do "campo hermenêutico", quando se estruturam novas configurações de autorreferência a partir das quais o homem moderno passa a enxergar a si mesmo como excêntrico ao mundo. Isso significa que ele passa a compreender-se enquanto "entidade intelectual incorpórea" (GUMBRECHT, 2010: 48) capaz de extrair um sentido inerente aos objetos do mundo, agora vistos como "coisas-em-si", puramente materiais, passíveis de serem “descobertas” pela razão.

Dussel situa esse paradigma do sujeito/objeto, constituinte da Modernidade, em momento anterior ao ego cogito cartesiano. Ao pensar criticamente a ideia de "descobrimento" pela clave do "encobrimento do outro", ele localiza a constituição desse novo sujeito moderno a partir da práxis dos primeiros conquistadores no Novo Mundo, que tratam os povos indígenas como objetos de suas individualidades violentas, “ob-jeto: lançado (jacere) diante (ob) de seus olhos.” (DUSSEL, 1993: 36). Teria sido, portanto, o ego conquiro dos conquistadores espanhóis no Novo Mundo, o marcador fundamental desse novo tipo de subjetividade moderna que nega o outro enquanto sujeito, fazendo dele "ob-jeto" de sua visão conquistadora.

Ao retomar a aproximação feita por Dussel entre a visão dominadora do "conquisto, logo existo" e o princípio epistemológico do "penso, logo existo", Grosfoguel atenta para o princípio genocida e epistemicida implicado nessa estrutura de conhecimento ocidental. Genocida por razões óbvias. Epistemicida porque nega o outro enquanto sujeito e, ao se autoinscrever como id-entidade incorpórea universal, constitui o "mito da egopolítica do conhecimento", ou seja, o mito do "ego que produz conhecimento imparcial" e, a partir daí, constrói a objetividade enquanto neutralidade (GROSFOGUEL, 2016: 30). Residiria nessa operação, fruto da constituição violenta do capitalismo colonial, o privilégio epistêmico que estrutura o conhecimento - com seus currículos, suas práticas e metodologias ocidentais - nas escolas e universidades.

O que estou denominando aqui de mito do "universalismo descarnado" é, portanto, essa estrutura de conhecimento gestada ao longo da formação do capitalismo colonial e que se autoinscreve como universal incorpóreo ao tempo em que apaga seu lugar de enunciação e reduz os colonizados à condição de objetos. Tal mito, dominante 
em nossas instituições ocidentais, foi analisada minuciosamente por Frantz Fanon a partir de um episódio cotidiano vivido por ele na França.

'Negro imundo!' Ou simplesmente: 'Olhe, um negro!'. Vim ao mundo preocupado em suscitar um sentido nas coisas, minha alma cheia do desejo de estar na origem do mundo, e eis que me descubro objeto em meio a outros objetos.

Encerrado nessa objetividade esmagadora, supliquei a outro alguém. Seu olhar libertador, delizando sobre o meu corpo subitamente livre de asperezas, restituiu em mim uma leveza que eu acreditava perdida e, afastando-me do mundo, devolveu-me ao mundo. Mas, lá, tropecei já na contravertente, e o outro, por meio de gestos, atitudes, olhares, fixou-me, como se fixa um corante com um estabilizador. Eu me enfureci, exigi uma explicação... Nada adiantou. Explodi. Eis aqui os estilhaços recolhidos por um outro eu. (FANON, 2005 - grifo meu)

Assim Fanon inscreve a "experiência vivida do negro" no livro Pele Negra, Máscaras Brancas. O corpo negro escrutinado pelo olhar do sujeito branco torna-se "objeto em meio a outros objetos" e assim, fraturado pelo olhar do terror racial, é jogado nessa "zona de não ser", nesse terreno vácuo de sub-humanidade. Restam-lhe estilhaços que apenas seu "outro eu” é capaz de recolher.

Assim como Césaire, Fanon compreende que o universalismo proposto pelo ocidente não inclui os seres objetificados ao longo do processso histórico da colonização. Ou seja, o "universalismo descarnado", embora se autoproclame universal, fecha-se num particularismo hegemônico daqueles que são considerados sujeitos, ou para retomar provocação de Ailton Krenak, o "clube da humanidade" (KRENAK, 2019: 8). Os corpos objetificados só podem existir a partir das particularidades estereotipadas pelo colonizador, ou seja, não lhes caberia qualquer possibilidade de universalismo. A partir de uma leitura de Fanon, Faustino usa o termo de “(des)universalização" para se referir a esse processo em relação ao negro:

A (des)universalização deste 'Outro' o aprisiona em uma essência fixa. 'o negro é isto' (corpo, sexo, cores, ritmos, etc.) e, portanto, 'não é aquilo...' (razão, civilização, universal, humano, etc.). Se o europeu é sinônimo do Humano, quanto mais o 'Outro' se distancie deste europeu, menos 
humanizado será... ao Negro nesta equação restará duas alternativas: reconhecer-se a partir daquilo que o Branco elege como seu-outro, ou negarse a si próprio em direção a esse Branco, tido como universal (MENDES FAUSTINO, 2013).

Nesse sentido, Césaire propõe construir 'um universal depositário de todo o particular'. Na mesma linha, Fanon propõe, em seu livro Pele Negra, Máscaras Brancas, um "novo humanismo". O advento do humanismo ocidental teria sido marcado pela experiência do avanço colonial e da auto inscrição do "humano" pela negação do outro racializado, obejtificado, animalizado. Ao invés de se constituir pela negação do outro e sua inscrição a uma "zona do não ser" (FANON, 2020), o "novo humanismo" seria a possibilidade de o homem ser um "SIM que vibra com as harmonias cósmicas" (FANON, 2020), ou seja, ser sujeito não apenas para si mesmo, mas também para o outro. Para isso, é preciso romper com o princípio do "universalismo descarnado" que se estruturou não apenas nas instituições de ensino, mas também nos projetos de sociedade e nos planos das cidades ocidentais. As linhas que seguem propõem um procedimento de escrita pelo corpo, através do corpo. Uma escrita que não apenas reflete criticamente sobre esses processos, mas também propõe uma prática de cura dessas feridas coloniais, principalmente no sentido de reconstrução das subjetividades e singularidades pela ativação de forças vitais das corporeidades ou, como propõe Fanon, pelo recolhimento dos estilhaços.

\section{Escrita-despacho: "eis aqui os estilhaços recolhidos por um outro eu"}

Escrita-despacho é um procedimento de escrita experimental que procura desenvolver-se atento aos elementos performativos do corpo em sua relação com os diferentes espaços, territórios, pessoas e materialidades que ele atravessa e pelos quais é atravessado. Através do corpo em caminhada, procuro entrever as feridas coloniais que nos perpassam, oriundas do processo histórico em que se consolidou a hegemônica modernidade ocidental. Trago o conceito de ferida colonial de Gloria Anzaldúa. Em seu livro Bordelands (1987), ela usa o termo para se referir à fronteira entre México e Estados-Unidos, "uma ferida aberta em que o Terceiro Mundo atrita contra o Primeiro Mundo e sangra". Feridas coloniais são as marcas físicas e psíquicas desse atrito. Se 
manifestam nos corpos, nas subjetividades e em seus territórios. São as marcas dos projetos de Modernidade e seus universalismos descarnados que violentam militar, mercantil, religiosa, pedagógica e epistemologicamente os corpos colonizados. Como os estilhaços apontados por Fanon, essas marcas nem sempre são visíveis. Pelo contrário, o projeto global de Modernidade tem por estratégia sempre escondê-las, já que tais marcas evidenciam o lado sombrio da Modernidade - a Colonialidade.

A escrita-despacho dialoga com o conceito de Modernidade/Colonialidade (MIGNOLO, 2003) para pensar criticamente os limites do moderno sistema mundial em sua relação oposta e complementar à Colonialidade. A Colonialidade é a longa duração dos saberes e das práticas coloniais que foram gestadas junto ao projeto de Modernidade ocidental e cujas feridas abertas evidenciam a continuidade das violências sobre os corpos objetificados por esses processos.

A escrita-despacho dialoga também com o exercício autoetnográfico. Em sintonia com a proposta de Daniela Versiani, desejo enfatizar a autoetnografia como uma grafia, isto é, um ato comunicativo performativo que busca superar as dicotomias entre auto e etno, entre subjetivo e objetivo, supondo que toda escrita referente ao outro é também uma escrita de si (VERSIANI, 2005). Marca-se assim uma quebra com a dicotomia sujeito/objeto que estrutura as epistemologias ocidentais.

A escrita-despacho é um exercício de subversão dos arquivos coloniais e de seus imperativos de "universalismo descarnado". Uma escrita que cria procedimentos para perturbar as oposições ocidentais entre mente/corpo, espírito/matéria, ciência/encanto, passado/futuro. Para isso assume a materialidade do encontro dos corpos como princípio de escrita, num "jogo de linguagem que se espacializa no corpo" (SODRÉ, 147). Procura uma proximidade com o que Conceição Evaristo - ao observar sua mãe inscrevendo o sol pelo jogo de corpo com as coisas, seu corpo-acocorado, o lápisgraveto e o chão-página - chamou de escrevivência (EVARISTO, 2007).

Escrita-despacho está em diálogo com a prática da deriva ${ }^{1}$, tal qual proposta por Guy Debord, e seu princípio de "deixar-se ir segundo as solicitações do terreno e os encontros que lhe correspondem" (DEBORD, 1958). No desejo de afastar-me de uma concepção a-priori do território, o programa proposto por Debord de deparar-se com rotas e coisas fortuitas, de criar achados aleatórios e casuais é uma forma de percepção

\footnotetext{
${ }^{1}$ Discuto melhor essas questões de deriva no texto "Banzar ao atá: por uma deriva etnográfica". In:
} 
que se afasta do controle racional e do domínio sentimental-psicológico do indivíduo, promovendo a experimentação corpóreo-sensorial e afetiva dos espaços.

Derivar pelas cidades sensoriando e ajuntando materialidades banais do cotidiano para serem despachadas em pontos de feridas coloniais. Este foi o exercício de escrita. Tais materialidades são as encenações verbais, sonoras, visuais e corporais que me colocam na presença imediata do espaço e me levam a descobrir princípios ativos em materialidades para as quais me entrego de modo afetivo e corporal. A escrita deste texto performatiza-se conjuntamente a tais materialidades transitórias, irrepetíveis e efêmeras.

É uma escrita que se constitui, portanto, através do espaço, da caminhada, do deslocamento corpóreo pelos territórios e suas fronteiras. Ao atravessar novamente as ruas, os monumentos e a escola em que passei parte de minha infância em Paris, busquei enxergar os resíduos coloniais à sombra destes lugares planejados pelo projeto de modernidade gestado na capital de um dos maiores Impérios coloniais. Tais resíduos atravessam a cidade e seus corpos. Pelas ruas, monumentos, coisas. Tais resíduos atravessam e confinam os corpos. Pelas escolas, e suas práticas de escrita que anulam a presença do corpo. Decido escrever a partir destas falhas materiais que me tomam o corpo e a partir das quais procuro reconstituir os "estilhaços".

Nesse sentido, a escrita-despacho está em diálogo com o que Rufino apresenta como ebó epistemológico, um "saber praticado" que procura redefinir a própria base da estrutura de conhecimento ao propor a lógica do feitiço e sua compreensão de troca de força vital pela comunhão da materialidade com a espiritualidade como produtores de saber. (RUFINO, 2019: 88). Despacho deve ser entendido, portanto, como um operador prático e conceitual que compreende a matéria e o espírito como fenômenos coextensivos, e que sua comunicação ativa a força vital dos corpos em movimento.

Nesse saber praticado, a escrita-despacho se ocupa dos pedaços de coisas de rua - dos estilhaços da colonialidade - como um santo se ocupa de seu cavalo. Fazer das coisas um cavalo de santo no qual se pode cavalgar, como corpos que se fundem numa unidade, mas que seguem existindo em suas diferenças, pluralidades. Corpos em sobreposição, numa relação de imanências. (ANJOS, 2006). Dessa relação cria-se um terceiro. Não mais o sujeito que "escreve", nem tampouco a coisa que é "escrita". Ambos se fundem numa produção de diferenças que se auto-inscrevem simultaneamente como "objetos-ativos" (SODRÉ, 2017: 118) num terceiro. Esse terceiro é o "outro eu" apontado por Fanon, capaz de recolher os estilhaços e 
decolonizar a objetificação que lhe foi imposta pela pedagogia do "universalismo descarnado".

\section{O que você esconde?}

Dos meus 7 a 10 anos de idade vivi em Paris, um dos mais importantes centros de irradiação do Império colonial e de sua pedagogia do "universalismo descarnado". Adentrei as engrenagens de seu sistema público de ensino em meados dos anos oitenta. Dessa experiência, extraio reflexões sobre tal pedagogia e também construo um saber praticado de escrita que busca curar as feridas coloniais referentes a essas vivências.

Aproximadamente 30 anos mais tarde, tenho a oportunidade de regressar aos lugares que fizeram parte de minha infância: basicamente a casa, a escola e o caminho de casa para a escola. Refaço então esse caminho que percorria todo dia. Ao longo do trajeto sempre cumprimentava uma estátua que ficava próxima à entrada do colégio. Muitas vezes passava ansioso diante dela. Quase toda semana tínhamos que decorar um texto e a professora escolhia aleatoriamente dois ou três alunos para declamá-lo. Costumava ficar repetindo o texto para mim até chegar em sala de aula. Quando não estava seguro com algum verso e passava diante da estátua, sentia medo e, muitas vezes, pensava em matar aula.

Dessa vez resolvo ler o nome do "herói" da estátua que sempre cumprimentava. General Mangin. Leio uma frase escrita abaixo de seu nome: "Fazer a guerra é atacar". Dou a volta na estátua e leio: "Três vezes ferido em Diena, Sudão (1889-1892). Oficial de Marchand Fachoda (1898). Cria o Exército Negro de Dakar (1906). Liberta Marrakech (1912)." Logo abaixo de sua biografia, inscrito em grandes caracteres: "A França é uma Nação de cem milhões de habitantes". General Mangin conquistou sua reputação ao longo das guerras coloniais francesas na África. Atuou na conquista do atual Mali (antigo Sudão francês). Participou como oficial na força francesa enviada a Fachoda (atual República do Sudão do Sul) para lutar contra os ingleses pelo domínio dos territórios da África oriental. Criou o Exército Negro de Dakar, composto por soldados senegaleses que formaram uma força conjunta fundamental para a conquista francesa do Marrocos, conquista esta que no monumento é eufemisticamente tratada como "libertação". 
Recordo mais uma vez Frantz Fanon. Ele se juntou às forças gaulistas no grupo de "voluntários antilhanos" durante a segunda guerra mundial. Fanon era um desses "cem milhões de habitantes" lutando por uma pátria que o excluía sistematicamente através do racismo totalitário e cotidiano da administração Vichy. Fanon estaria representado nessa estátua? Diz ele:

O colono faz a história e sabe que a faz. E, porque se refere constantemente à história de sua metrópole, indica claramente que ele é, aqui, o prolongamento dessa metrópole. [...] Mundo compartimentado, maniqueísta, imóvel, mundo de estátuas: a estátua do general que fez a conquista, a estátua do engenheiro que construiu a ponte. Mundo seguro de si, esmagando com suas pedras as colunas dorsais esfoladas pelo chicote. Esse é o mundo colonial. O indígena é um ser confinado [...] A primeira coisa que o indígena aprende é ficar no seu lugar, a não passar dos limites. É por isso que os sonhos indígenas são sonhos musculares, sonhos de ação, sonhos agressivos (FANON, 2005: 68).

Fanon seria mais um destes soldados a lutar pela libertação da França, mas que "permanece alienado em seu próprio país, e vive num estado de despessoalização absoluto" (FANON, 2005: 7). Os "despessoalizados" nunca se tornariam estátuas, nem teriam história. A estátua que lhes caberia é o estado de petrificação, o confinamento dos corpos a limites territoriais, temporais e psíquicos. De frente para a estátua do general ou entre os corredores da escola, sentia-me igualmente submetido ao confinamento de corpo. Confinamento psíquico e físico.

Nesses tempos eu era visto como árabe. Nos anos oitenta era muito forte a presença de imigrantes vindos da Argélia e, principalmente, do Marrocos. Provavelmente por isso, devido ao processo intersubjetivo de atribuição identitária, eu tenha incorporado essa identidade árabe. Meus amigos de colégio eram quase todos marroquinos. Por outro lado, a escola e seus arredores estavam cercados de lugares de memória que traziam à tona uma presença francesa que parecia afirmar-se justamente através de seu domínio sobre esse outro, continuamente invisibilizado nos interstícios da construção de uma memória nacional. "A França é uma nação de cem milhões de habitantes". A princípio, somos levados a crer, tendo em vista o texto que acompanha a frase da estátua, que os sudaneses, malinenses, senegaleses e marroquinos "conquistados" durante as guerras de colonização das quais participou o General seriam 
também franceses. Viro-me para o extremo norte da esplanada onde estou e me deparo com o imponente Invalides, onde se encontra o mausoléu de Napoleão Bonaparte.

Qu'est-ce que tu caches [O que você esconde]? Essa frase estava escrita numa faixa colada a um muro enquanto derivava por alguma rua. Ela me fez ressoar algo. Cometi o pequeno ato ("vândalo"?) de retirá-la de seu lugar. Vejo agora que o monumento que heroiciza o General Mangin esconde milhares de mortes decorrentes das invasões coloniais: sudaneses, malinenses, senegaleses e marroquinos. Sintomaticamente, o que o monumento anuncia não são as mortes dos outros, mas a pretensa unidade daqueles que sobreviveram, os idênticos: "A França é uma Nação de cem milhões de habitantes". Qu'est-ce que tu caches [O que você esconde]?

Como afirma Koselleck, os monumentos não lembram apenas os mortos, eles também lamentam a vida perdida para dar sentido aos sobreviventes (KOSELLECK, 1997: 179). É esse sentido da pretensa unidade dos que sobreviveram que vejo desenhando-se desde agora, quando revisito as fotos do despacho que realizei diante do mausoléu de Napoleão. Consigo vislumbrar um sentido de afirmação identitária nacional que se faz pela colonialidade invisibilizada. Os "cem milhões de franceses" têm sua sobrevivência garantida enquanto memória porque há "cem milhões de africanos" mortos, desaparecidos e invisibilisados nas entrelinhas de seus monumentos. Quando seu corpo está em contato cotidiano com as dinâmicas da colonialidade, é impossível não as identificar entre os ícones de memória nacional e identitária ali expostos. Napoleão, o Imperador que personifica o símbolo maior da identidade francesa foi, não por acaso, um dos principais articuladores do avanço imperial pelo Oriente, inaugurando o modelo de expansão colonial francês. Segundo Said, foi a invasão do Egito por Napoleão em 1798 e sua incursão pela Síria que tiveram "de longe a maior consequência para a história moderna do Orientalismo". (SAID, 2007: 118)

Said enxerga as minúcias do projeto de invasão do Egito articuladas por Napoleão como uma cena inaugural daquilo que, logo em seguida, veio a se tornar o orientalismo. Tal projeto fundamentou-se, para além das estratégias militares, numa atitude textual. Segundo Said, as estratégias de atuação colonial de Napoleão tinham como principal inspiração a leitura de memórias de viagem ligadas ao Oriente, sobretudo o livro Voyage en Égypte et en Syrie (1787), do Conde de Volney. A "atitude textual" de Napoleão em relação ao Egito fez com que levasse, em sua primeira expedição, uma academia completa de estudiosos, além de ter criado, em Paris, uma école publique na Bibliothèque Nationale para ensinar árabe, turco e persa com o 
objetivo racionalista de institucionalizar o conhecimento sobre o outro. Numa típica atitude hermenêutica, Napoleão acreditava estar dando significação histórica, geográfica e cultural a uma região supostamente perdida em sua barbárie contemporânea. Sua expedição militar tinha pretensões hermenêuticas, isto é, desvelar a História desses povos que foram tão importantes, num passado remoto, para a consolidação do conjunto de saberes e aperfeiçoamentos que culminaram na Civilização racional europeia. Napoleão estaria, portanto, retirando o Egito de sua "barbárie" presente para restaurar sua antiga grandeza clássica. Como resume Said:

[...] instruir o Oriente (para seu próprio benefício) nos modos do Ocidente moderno; subordinar ou minimizar o poder militar para engrandecer o projeto do glorioso conhecimento adquirido no processo de dominação política do Oriente; formular o Oriente, dar-lhe forma, identidade, definição com pleno reconhecimento de seu lugar na memória, sua importância para a estratégia imperial e seu papel 'natural' como apêndice da Europa; dignificar todo o conhecimento coligido durante a ocupação colonial com o título 'contribuição para a erudição moderna', quando os nativos não tinham sido nem consultados, nem tratados senão como pretextos para um texto cuja utilidade não se destinava a eles; sentir-se como um europeu a comandar, quase à vontade, a história, o tempo e a geografia orientais; instituir novas áreas de especialização; estabelecer novas disciplinas; dividir, organizar, esquematizar, tabular, indexar e registrar tudo à vista (e fora da vista); fazer de cada detalhe observável uma generalização e de toda generalização uma lei imutável sobre a natureza, o temperamento, a mentalidade, o costume ou o tipo oriental; e acima de tudo, transmutar a realidade viva na matéria de textos, possuir (ou pensar possuir) a realidade [...] Assim Fourier conclui o seu prefácio anunciando que a história lembrará como 'o Egito foi o teatro de sua glória, e preserva do esquecimento todas as circunstâncias desse acontecimento extraordinário' (SAID, 2007: 131).

$\mathrm{Eu}$ era mais um desses corpos transformados no teatro das representações ocidentais do outro. Tratar as feridas coloniais. Vejo-me agora exatamente entre o mausoléu de Napoleão e a saudosa esplanada. A experiência pessoal renovada. Bem no momento em que chego para realizar o despacho, há uma caravana de turistas indianos pousando para fotos. Um casal me pediu para fotografa-los com os Invalides ao fundo. Uma caravana de indianos pousando para fotos tendo como cenário o monumento em 
que se encontra inumado o corpo de Napoleão, um dos grandes arquitetos do Orientalismo. (Ver Imagem 1)

Começo a sacar os pertences a serem despachados: uma faixa que arranquei de um muro com os dizeres Qu'est-ce que tu caches? [O que você esconde?]. O pedaço de uma frase que descasquei de outro muro com as palavras incompletas Pas de pays, des differe... [Não há países, há difere...] Uma caixa de rapé encontrada no chão com o nome sugestivo de Maklaifriquia. Uma caixa encontrada na rua com os dizeres $L a$ cuisine porte-bonheur. [A cozinha que traz sorte]. Uma asa de pássaro que jazia solta na calçada. Um pedaço de cabaça que trouxe de Marrakech. Enquanto vou tirando da sacola as materialidades, eis que surgem três senegaleses vendedores de souvenirs franceses. Compro deles a base que faltava para agrupar as coisas do despacho: um pano escrito PARIS. (Ver Imagem 2).

Imagem 1: Visão panorâmica da realização do despacho em frente aos Invalides, mausoléu de Napoleão Bonaparte e os turistas indianos

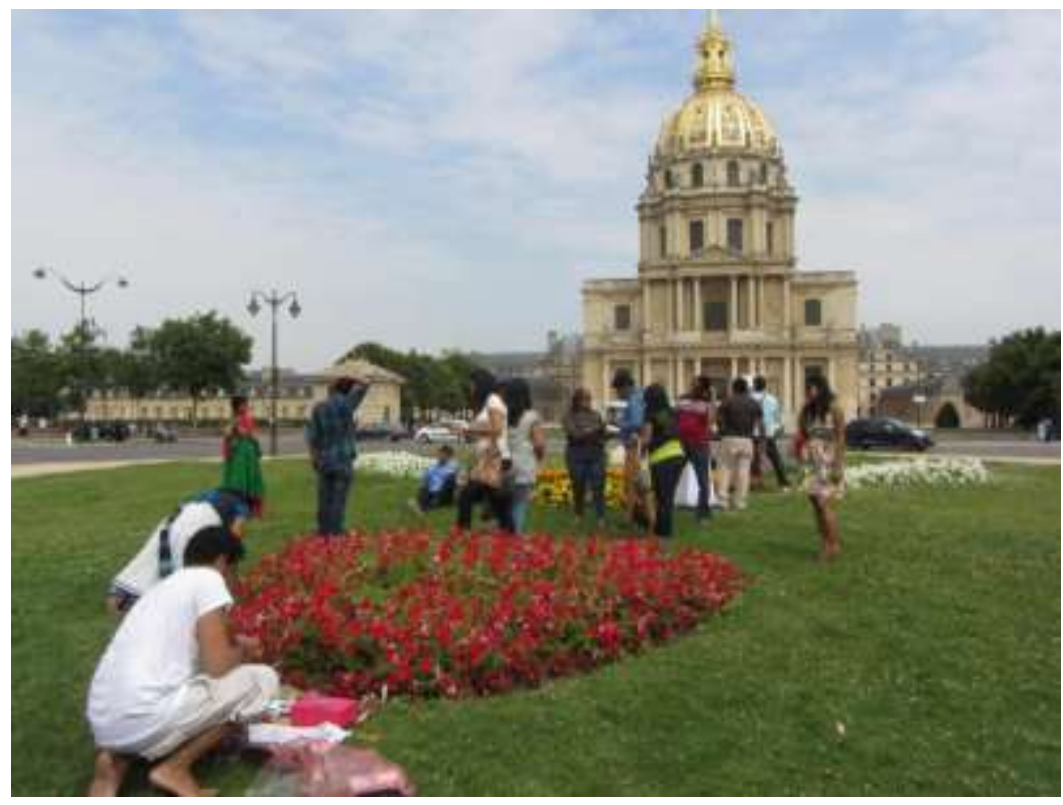

Fonte: Acervo pessoal, foto tirada por Dado Amaral. 
Imagem 2: Detalhe do despacho realizado em frente aos Invalides, mausoléu de Napoleão Bonaparte.

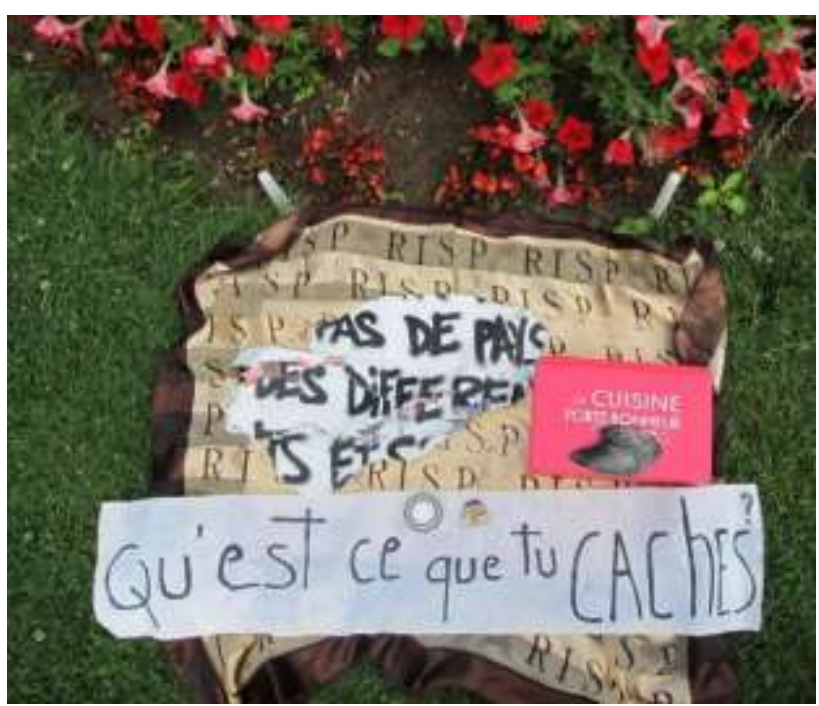

Fonte: Acervo pessoal, foto tirada por Thiago Florencio.

O que os desenhos desse despacho, em toda sua conjuntura performativa imediata, fazem-me ver? Fazem-me ver interstícios da invisibilidade colonial. Turistas indianos empolgados e imigrantes senegaleses tentando a vida, estamos todos aqui, os corpos outros, aglomerados em torno do inumado corpo napoleônico, este que se acreditava o "universal descarnado" capaz de reunir e indexar a nós, os corpóreos objetiváveis, para iluminar a marcha da Civilização. O "universal descarnado" acredita que seu olhar desgarrado do mundo pode organizar e dar sentido àqueles corpos presos à materialidade, os corpos outros. O “universal descarnado”, com sua Razão arquivista, subtrai-lhes pertences e objetos tendo em vista a missão de iluminar e preservar a memória do passado da Humanidade. Missão civilizadora. Esse saque em nome da preservação dos arquivos do passado oblitera as ações que foram empreendidas na aquisição de tais objetos "primitivos". Indexados e catalogados, eles circulam nos assépticos corredores de museus como Louvre ou Quai Branly, escondendo a história colonial que os fez chegar até lá. O que você esconde?

Arquivos que, associando o "poder arcôntico" ao "poder de consignação" (DERRIDA, 2001: 13), reúnem e comandam as origens da marcha da Civilização ${ }^{2}$. O sufixo - ação dessa nova palavra de ordem da modernidade ocidental implica em pensar

\footnotetext{
${ }^{2}$ Segundo Derrida, o termo grego arkhê significa tanto "começo" quanto "comando". Determinar um começo é operar o comando, através da consignação, isto é, a reunião dos signos para que "todos os elementos articulem a unidade de uma configuração ideal" (DERRIDA, 2001: 12,14).
} 
uma ação e um agente para tal ação. Como pontua Starobinski, o importante não é "lembrar as diferentes teorias ou filosofias da história, mas sublinhar o fato de que ao denominar "civilização" o processo fundamental da história, e ao designar pelo mesmo nome o estado final resultante deste processo, coloca-se um termo que contrasta de forma antinômica com um suposto estado primitivo (natureza, selvageria, barbárie)" (STAROBINSKI, 1989: 17).

Vale lembrar que o termo "civilização" começa a ser utilizado de forma recorrente na língua francesa no período pós-revolucionário. Derivado dos termos civil (século XII), civilité (século XIV) e do verbo civiliser (século XVI), é apenas em finais do século XVIII que ele é incorporado definitivamente à língua escrita, tornando-se verbete do Nouveau Dictionnaire français (1795) de L. Snetlage:

Essa palavra [...] é empregada para expressar a ação de civilizar ou a tendência de um povo de polir ou melhor de corrigir seus usos e costumes trazendo dentro da sociedade civil uma moralidade luminosa, ativa, amante e abundante de boas obras. (Todo Cidadão da Europa está atualmente engajado neste combate de civilização. Civilização dos costumes). (SNETLAGE apud STAROBINSKI, 1989 (tradução do autor))

Nota-se que seu sentido é pensado enquanto uma ação que visa "polir" e "corrigir" tendo em vista o objetivo de se chegar a uma "moralidade luminosa". Tal moralidade implica uma marcha da Humanidade em que está imerso todo "Cidadão da Europa": do primitivo ao civilizado, marcha que marca a ideia de uma ruptura definitiva entre um passado tradicional, e um futuro que se encaminha para o aperfeiçoamento da espécie, para o progresso do espírito humano, enfim - para a Civilização.

Apesar de concordar com Said quanto à prevalência de Napoleão no exercício do orientalismo, já que inaugura uma forma "textual" de aproximação com países do Oriente-Médio, convém lembrar que tal atitude textual já estava presente no exercício cotidiano da expansão colonial ibérica pelas Américas. Por isso, em sintonia com Mignolo, penso que não se pode pensar o "orientalismo" oitocentista sem antes compreender a formação do "ocidentalismo" seiscentista, decorrente da colonização das Américas. O "ocidentalismo" é o "imaginário geopolítico dominante do sistema mundial colonial/moderno, ao qual o "orientalismo" foi anexado em sua primeira transformação radical, quando o centro do sistema se deslocou da Península Ibérica para 
o Mar do Norte, entre a Holanda e a Grã-Bretanha" (MIGNOLO, 2003: 90). O “ocidentalismo" consolidou-se enquanto celeiro da modernidade ao utilizar o corpo e o território ameríndio como locus da escrita de sua própria história. Reduzidos à condição de "papel branco" (FLORENCIO, 2007) os corpos indígenas deveriam ser significados pela ação missionária, responsável pela inscrição destes povos na narrativa cristã da salvação. Tal escrita da salvação seiscentista desdobrou-se posteriormente na escrita da "civilização": sobre o corpo "selvagem" inscreveu-se o ideal de um povo superior, moderno e civilizado.

A ideia de progresso e civilização pode ser pensada como desdobramento secular da noção de tempo do cristianismo. Ao introduzir a ideia de um tempo finito e irreversível, contrastante com a eternidade edênica, o cristianismo "acentuou a heterogeneidade do tempo; isto é, pôs manifestamente essa propriedade que o faz romper consigo mesmo, dividir-se, separar-se, ser outro sempre diferente." (PAZ, 2013: 32). Octavio Paz entende por época moderna o período que se inicia no século XVIII e que marca a "conquista do mundo histórico" (CASSIRER, 1997: 27), por se caracterizar pela apreensão, a partir da experimentação científica que alia a razão ao empirismo, das verdades eternas e universais da natureza. Os iluministas asseguram o domínio da marcha da História, que passa a ser agora singular, universal, direcionada para um fim que é o progresso, o aperfeiçoamento incessante do espírito humano. Iluminam um novo tempo, governado pela consciência desse motor da História: o olhar volta-se para o que Paz denominou "colonização do futuro".

A disputa entre Razão e Revelação inaugura a modernidade, essa época autocrítica que rompe constantemente consigo mesma. Os Ocidentais fazem da natureza seu laboratório e do "selvagem" seu objeto de cisão no tempo: do natural ao civilizado, do tradicional ao moderno. Os "selvagens" seriam escravos de seus próprios corpos, dos quais parecem incapazes de se desgarrar sem que haja a interferência civilizacional. Caberia aos povos iluminados pela graça da Razão salvá-los, ou civilizá-los. Os "civilizados", supondo-se "incorpóreos universais", acreditam-se os garantes desse ato contínuo e transformador: polir, retirar as camadas ásperas e grosseiras que habitam o corpo "selvagem" ou "primitivo". Polir não só o corpo, mas os costumes, aperfeiçoando a espécie humana, tornando as pessoas polidas, comportadas, enfim, civilizadas. Apesar de diferentes raízes, polir pode se associar a policiar, ou até mesmo a polis, cidade, local onde habitam os cidadãos, os que têm logos, organização política, em contraste com 
aqueles que habitam as selvas, silvícolas ou bárbaros, incapazes de articular a linguagem e a lei (STAROBINSKI, 1989: 33).

Meus anos de educação em Paris foram marcados pela polidez da Missão Civilizadora. Tal polidez está presente em detalhes que interferiam diretamente no uso que fazíamos de nossos corpos e na sua relação com o universo do saber e da escrita. Lembro-me da importância acordada aos cadernos e da relação de extremo zelo que devíamos ter com eles. Tal zelo implicava em tratá-los de forma imaculada, como se representassem o afastamento que o universo das letras devia operar de nossos corpos como veículo de sentido. Éramos sistematicamente orientados a tomar uma atitude de distanciamento do corpo em relação ao caderno: quanto menos rastros e resíduos corporais sobre ele, melhor. Enquanto escrevíamos com uma mão, a outra tinha que se apoiar sobre um papelão de modo que evitássemos o contato direto da palma com as páginas brancas. Qualquer sujeira era notada e malvista pela professora. Os cadernos tinham que estar impecáveis em sua imaculada brancura. Além disso, havia o exercício milimétrico da caligrafia. Os cadernos escolares franceses são quadriculados. Cada quadrado é composto por três linhas horizontais. As letras maiúsculas tinham que encostar precisamente na última linha horizontal, assim como as letras minúsculas que se alongam verticalmente $\mathrm{d}, \mathrm{f}, \mathrm{k}, \mathrm{l}, \mathrm{t}, \mathrm{h}$. Há também as letras que se alongam para baixo, nesse caso elas deviam estender-se até a segundo linha horizontal no plano inferior. Tais letras são g, j, p, q, y. As letras restantes tinham que se acomodar na primeira linha. Escrever era adequar cada letra à matemática linear dos quadrados. (Ver Imagem 3). 


\section{Imagem 3 - Detalhe de meu caderno escolar}

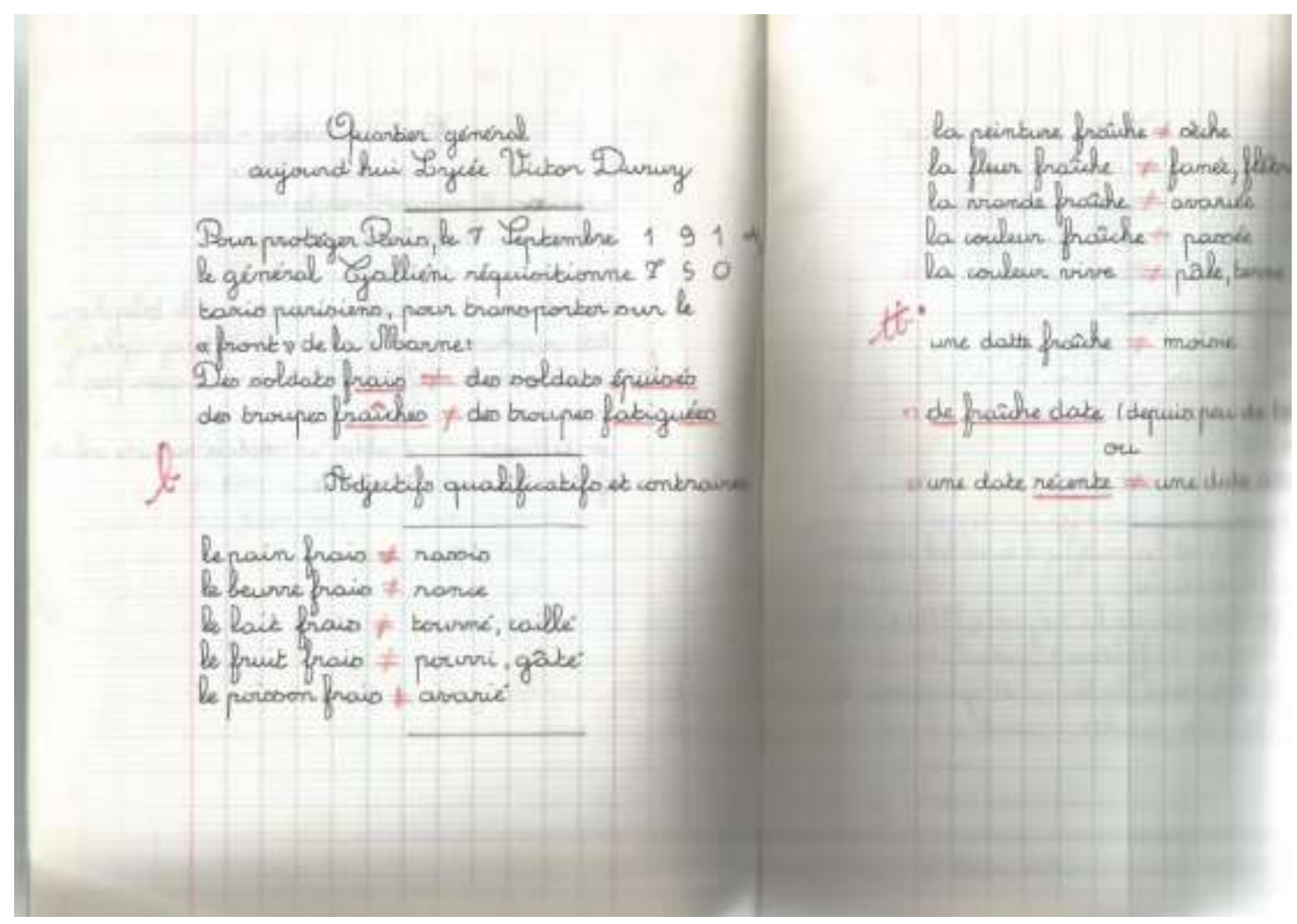

Fonte: Acervo Pessoal.

Os cadernos franceses seguiam à risca o sistema de coordenadas cartesiano. Cada quadradinho era uma coordenada $x$ e $y$ através da qual devíamos adequar as letras. Hoje arriscaria dizer que esses cadernos funcionavam como um exercício de afastamento gradual do corpo como veículo de sentido. A mediação necessária para garantir ao infante seu ingresso na subjetividade racional incorpórea, no "universalismo descarnado". Os cadernos apresentam as fórmulas fundamentais para tal afastamento: as coordenadas cartesianas e a assepsia através da qual evitava-se ao máximo o envolvimento corporal entre o aluno e seu caderno. Dois ingredientes básicos da polidez civilizacional. Em nome da construção de um sujeito abstrato separado do mundo das coisas, eram os cadernos os mediadores de nosso progressivo alcance da condição de "incorpóreos", “descarnados”. Que educação é essa, senão aquela que garante o ingresso da criança no mundo da civilização? Não seriam os cadernos máquinas de polir, mediadores da separação entre corpo e escrita, entre sujeito e objeto, entre natureza e cultura? Não seriam esses "inocentes" caderninhos o operador pedagógico da "Missão civilizadora". Como sublinha Starobinski: 
Em vista da perfeição do polido, o bárbaro é uma espécie de criança, a criança uma espécie de bárbaro. Para quem deseja acentuar o perigo da barbárie, não será difícil distingui-lo entre nós, no povo das longínquas províncias, nas crianças largadas a esmo, em todo lugar no qual a polidura educacional não foi capaz de intervir; para quem confia nos poderes da educação, não será árduo, correlativamente, considerar os selvagens como crianças, que uma benevolente e paciente polidura não seja capaz de transformá-los em semelhantes a nós (STAROBINSKI, 1989: 29).

A pedagogia polidora francesa garantiu-me a suspensão da união imediata entre corpo e escrita. Diria, talvez um pouco exageradamente, que os cadernos escolares funcionavam como pequenas máquinas de imprensa no sentido que Gumbrecht conferiu a este aparato que possibilitou, no início da modernidade, a separação gradual entre corpo e escrita (GUMBRECHT, 1998: 132). A experiência da escrita na escola, sujeita ao sistema de coordenadas cartesiano e a uma relação polidora entre o corpo e o caderno, parecia funcionar como a entrada radical no campo hermenêutico. A criança que atinge o estado incorpóreo vê-se capaz de operar um distanciamento crítico em relação à observação das coisas do mundo e, por isso, sair do suposto estado de barbárie e infantilidade. O projeto polidor implicado no sistema educacional público francês tem como fundamento operar o distanciamento do corpo como veículo de sentido e, por conseguinte, garantir a entrada do infante/bárbaro na vida civil, civilizada.

Finalmente, volto à pergunta “O que você esconde?", agora implicado na experiência escolar pública francesa, e arrisco: a pedagogia - pelo menos esta que vivenciei não só no sistema público primário francês em meados dos anos oitenta, mas também caminhando entre as ruas e monumentos do bairro - parece esconder a situação colonial em que se insere seu "universalismo descarnado". Pensando junto com Grada Kilomba, tal universalismo descarnado esconde a própria condição da branquitude:

Branquitude, como outras identidades no poder, permanecem sem nome. É um centro ausente, uma identidade que se coloca no centro de tudo, mas tal centralidade não é reconhecida como relevante, porque é apresentada como sinônimo de humano. Em geral, pessoas brancas não se veem como brancas, mas sim como pessoas. A branquitude é sentida como a condição humana. No entanto, é justamente esta equação que assegura que a branquitude continue sendo uma identidade que marca outras, permanecendo não 
marcada. E acreditem em mim, não existe uma posição mais privilegiada do que ser apenas a norma e a normalidade (KILOMBA, 2016, online).

Depois de dispor os objetos do "despacho" sobre o pano que comprei do senegalês, acendo duas velas e o pedaço de cabaça que recebi de um curandeiro marroquino. Segundo ele, a fumaça da cabaça, ao ser inalada, cura dor de cabeça. Acendo a cabaça. Inalo sua fumaça e sinto o corpo dilatar-se até ressoar a famosa frase de Fanon: "Oh meu corpo, faz sempre de mim um homem que questiona!" (FANON, 2020: 242).

Os corpos racializados pelo projeto colonial são justamente aqueles capazes de identificar e questionar o princípio epistemológico do "universalismo sem corpo", princípio este que caracteriza a pedagogia da branquitude, que se inscreve como universal enquanto objetifica e reduz o colonizado à sua existência particular e corporal. O caminho experimental da "escrita despacho", cujo princípio de acionar um pensamento atravessado pelas forças vitais do corpo, efetiva uma possibilidade de romper com as amarras dessa pedagogia que se camufla enquanto incorpórea e que atravessa as cidades e seus monumentos, as escolas e seus métodos de pedagogia escriptocêntrica.

\section{Referências bibliográficas}

ANJOS, José Carlos Gomes dos (2006). No território da linha cruzada: a cosmopolítica afro-brasileira. Porto Alegre: Editora da UFRGS - Fundação Cultural Palmares.

ANZALDUA, Gloria (1987). Borderlands/La Frontera. The new mestiza. San Francisco: La Frontera.

CASSIRER, Ernst (1997). A filosofia do iluminismo. São Paulo, Unicamp.

CÉSAIRE, Aimé (1956). Parternalismo e Fraternismo. Carta a Maurice Thorez, 1956. In: https://plataformagueto.wordpress.com/2017/02/11/carta-a-maurice-thorezpaternalismo-e-fraternalismo-de-aime-cesaire-deputado-da-martinica-traduzidado-frances-pela-plataforma-gueto-do-site-httplmsi-net-fevereiro-de-2017/ Acesso em: 12 set. 2020.

DEBORD, Guy (1958). Teoria da deriva. Internationale Situationiste no. 2. Dez. In: http://debordiana.chez.com/francais/is2.htm\#theorie. Acessado em 10/03/2014.

DERRIDA, Jacques (2001). Mal de arquivo: Uma impressão freudiana. Rio de Janeiro: Relume Dumará.

DUSSEL, Enrique (1993). 1492: O encobrimento do Outro. A origem do "mito da Modernidade”. Editora Vozes, Petropolis.

EVARISTO, Conceição (2007). Da grafia desenho de minha mãe, um dos lugares de nascimento de minha escrita. In: ALEXANDRE, Marco. Representações 
performáticas brasileiras: teorias, práticas e suas interfaces. Belo Horizente, Maza Edições.

FANON, Frantz (2005). Os condenados da terra. Juiz de Fora: Editora UFJF.

FANON, Frantz (2020). Pele negra, máscara branca. São Paulo, Ubu Editora.

GROSFOGUEL, Ramón (2007). El giro decolonial. Reflexiones para una diversidad epistémica más allá del capitalismo global. Compiladores Santiago Castro-Gómez y Ramón Grosfoguel. - Bogotá: Siglo del Hombre Editores; Universidad Central, Instituto de Estudios Sociales Contemporáneos y Pontificia Universidad Javeriana, Instituto Pensar.

GROSFOGUEL, Ramón (2016). A estrutura do conhecimento nas universidades ocidentalizadas: racismo/sexismo epistêmico e os quatro genocídios/epistemicídios do longo século XVI. Revista Sociedade e Estado Volume 31 Número 1 Janeiro/Abril

GUMBRECHT, Hans Ulrich (1998). Modernização dos sentidos. São Paulo: Ed. 34.

GUMBRECHT, Hans Ulrich (2010). Produção de presença: O que o sentido não consegue transmitir. Rio de Janeiro: Contraponto: PUC-Rio.

KILOMBA, G. Descolonizando o conhecimento: Uma Palestra-Performance de Grada Kilomba. 2016. Disponível em: Acesso em: 15 jun. 2020.

KOSELLECK, Reinhardt (1997). L'expérience de l'histoire. Paris: Seuil/Gallimard.

KRENAK, Ailton (2019). Ideias para adiar o fim do mundo. São Paulo: Companhia das Letras.

MENDES FAUSTINO, Deivison (2013). A emoção é negra, a razão é helênica? Considerações fanonianas sobre a (des)universalização do "Ser" negro Tecnologia e Sociedade, vol. 9, núm. 18, 2013 Universidade Tecnológica Federal do Paraná Curitiba, Brasil.

MIGNOLO, Walter (2003). Histórias locais: Projetos globais - colonialidade, saberes subalternos e pensamento liminar. Belo Horizonte: UFMG.

PAZ, Octavio (2013). Os filhos do barro: Do romantismo à vanguarda. São Paulo: Cosac Naify.

QUIJANO, Anibal (2005). Colonialidade do poder, Eurocentrismo e América Latina. In: LANDER, E. (org). A colonialidade do saber: eurocentrismo e ciências sociais. Perspectivas Latino-americanas. Buenos Aires: CLACSO.

SAID, Edward (2007). Orientalismo: O Oriente como invenção do Ocidente. São Paulo: Companhia das Letras.

SODRÉ, Muniz (2017). Pensamento Nagô. Petropolis, Editora Vozes.

STAROBINSKI, Jean (1989). Le remède dans le mal: Critique et légitimation de l'artifice à l'âge des Lumières. Paris: Gallimard.

VERSIANI, Daniela (2005). Autoetnografias: Conceitos alternativos em construção. Rio de Janeiro: 7Letras.

Artigo recebido em 15 de março de 2021.

Aprovado em 18 de junho de 2021.

DOI: 10.12957/intellectus.2021.58411 